The original publication is available at http://www.tandf.co.uk/journals/

\title{
Change in the shoaling behaviour and nutritional condition of anchovies (Engraulis encrasicolus L.) during a wind-induced water column disturbance: a natural event test of a general hypothesis
}

\author{
Jean-Pierre Bergeron ${ }^{\mathrm{a},{ }^{*}}$; Jacques Massé ${ }^{\mathrm{a}}$ \\ a IFREMER, Centre Atlantique, Département Écologie et Modèles pour l'Halieutique (EMH), \\ rue de l'lle d'Yeu, BP 21105, F-44311 NANTES CEDEX 03, France \\ * Corresponding author: Jean-Pierre Bergeron, Tel. (33) 2 40374162, Fax (33) 2 40374075, email address : \\ jean.pierre.bergeron@ifremer.fr
}

\begin{abstract}
:
Fishermen have long observed the sudden change of shoaling behaviour of small pelagic fish following a strong wind event. The phenomenon was thereafter confirmed by fisheries scientists using acoustic tools. In this study, we report our observations made with acoustics to measure disorganization of the previously observed spatial distribution and shape of shoals that occurred after a wind event. The measurements were made during a fisheries research cruise in the Bay of Biscay (NE Atlantic) aimed at determining (1) small pelagic fish species abundance and (2) the individual nutritional state of anchovies (Engraulis encrasicolus L.) via evaluation of their RNA/DNA ratio. A spatial fine-scale study was conducted in two of the main breeding areas for anchovy, one located near the plume of a large river (haline stratification) and the other in an open sea location over the continental shelf break (thermal stratification). After a strong wind event, a change of the spatial and bathymetric distribution of the fish community, including anchovy, was observed in the open sea area, whereas no effect was detected in the near shore area. The RNA/DNA ratios determined in anchovy white muscles were quite similar in both areas before the wind event. Afterwards, they remained unchanged near the shore but were significantly reduced in the open sea location. This difference can be explained by the disparity in the strength of the stratification (i.e. haline versus thermal), but a change in the species composition of the fish community may also have played a role.
\end{abstract}

Keywords: Engraulis encrasicolus L; anchovy; behaviour; acoustics; Bay of Biscay; nutritional condition; RNA/DNA ratio 


\section{Introduction}

The renewal of fish stocks to maintain a satisfactory biomass level that will allow their exploitation is the main concern of fisheries management. This renewal directly depends on the recruitment process, in which the breeding of the parent population plays an essential role. Temperate marine fish, especially small pelagic species, typically spawn large numbers of eggs during a season, which generally lasts for numerous weeks and sometimes for several months. In the Bay of Biscay (NE Atlantic), the spawning period for the European anchovy, Engraulis encrasicolus L., extends from April to July-August, with a peak in MayJune (Motos et al. 1996).

The breeding season requires high amounts of metabolic fuel, and parent fish must either consume their energetic stores (i.e. lipids) or feed on prey. Both processes most likely are involved in the functioning of gonads, because as the fat content of a fish progressively decreases (Ribeiro et al. 1996), energy has to be drawn from ingested prey (Blaxter and Hunter 1982). The nutritional value of food is classically estimated through its effect on individual fish, for instances by determining a condition index. Several condition indices have been proposed, and they can be roughly classified into two categories according to the life duration characteristics of the species and length of time considered. Long-term condition indices are based mainly on morphometric criteria, such as the Fulton's condition factor $\mathrm{K}$ that is based on the length-weight relationship, is probably the most widely used (Fulton 1904; Nash et al. 2006). On the other hand, nucleic acid-based indices are more relevant for assessing short-term variations of nutritional condition, especially in small pelagic species such as anchovy that are characterised by a highly active metabolism. The RNA/DNA ratio determined in white muscle tissue has proved to be a reliable index of nutritional condition (Bergeron 1997; Chicharo and Chicharo 2008).

The anchovy population in the Bay of Biscay generally spawns in two main areas that are characterised by radically different oceanographic conditions. One area is directly influenced by a large river plume from the Gironde freshwater dilution and is therefore relatively shallow with strong haline stratification. The other is situated over the shelf break where tidally induced upwelling brings high salinity and nutrient-rich water up to the surface, affecting primary production (Bergeron et al. 2009). Therefore, both areas, despite the difference in enrichment processes, present conditions for high biological productivity and have been the subject of extensive comparative studies which concern a wide spectrum of organism sizes, from phytoplankton (Lampert et al. 2002), nano-microplankton (Zarauz et al. 2007), mesozooplankton (Plounevez and Champalbert 1999; Albaina and Irigoien 2004) and up to highest trophic levels such as birds (Certain et al. 2007) and large mammals (Certain et al. 2008).

The anchovy population of the Bay of Biscay has been subjected to recurrent annual acoustic surveys during the spawning season since the early 1990s. Small pelagic fishes were sampled with pelagic trawls when echograms indicated the presence of shoals. From 1993 onwards, anchovies were sub-sampled in the catches with the aim of assessing their nutritional condition through RNA/DNA ratios. During the 1993 cruise, an exceptional strong wind event occurred (up to 20-30 knots continuously for 3 days). This event clearly affected the vertical structure of the water column (Bergeron 2000). The nutritional condition of anchovy larvae was lowered, which was regarded as an ensuing consequence of this disruption of the stability of the water column (Bergeron 2000). Such phenomena are fairly well documented in the literature devoted to primary consumers such as copepods or fish larvae. In contrast, reports about the consequences of wind events on the metabolism or the behaviour of larger marine animals with greater mobility are much less common. Herein we describe the effect of a strong wind event on the behaviour of small pelagic fish shoals as observed using acoustic tools and on the nutritional condition of anchovies as assessed using the RNA/DNA ratio. 


\section{Materials and methods}

For nearly two decades, our research team was involved in annual evaluations of the anchovy stock in the Bay of Biscay. The environmental conditions of each survey were systematically recorded. Among these conditions, wind strength is well known and recognised by fishermen (Gerlotto et al. 1997) to affect the behaviour of small pelagic fishes. Within these long data series, the most dramatic wind event occurred in 1993. We therefore re-analysed the data from the 1993 cruise.

The ERAG (Ecologie et Recrutement de l'Anchois du golfe de Gascogne) cruise was conducted in 1993 (5-21 June) on board RV Thalassa. This survey had two main purposes: i) to assess the anchovy biomass and distribution during the spawning period and ii) to define environmental factors that could influence recruitment. With these aims in view, during the first leg of the cruise the whole southern Bay of Biscay was exhaustively surveyed using acoustics to determine the anchovy distribution and its environment (Massé et al. 1996). A second leg was devoted to clarifying temporal and spatial fluctuations of adults and larvae by surveying two particular areas on a finer scale (Figure 1): one site was a triangular area close to the Gironde estuarine plume (GIR area) and the second was a rectangular area close to the continental shelf break (FAC area, from the local name "Fer à Cheval" given by the fishermen). Anchovies were present in both areas; they were mixed with sardines and sprat in the GIR area and with horse mackerel (Trachurus trachurus) in the FAC area.

\section{Acoustics and fishing}

Acoustic data were collected only during daytime due to anchovy behaviour in this area. Anchovies usually disperse very close to the surface at night and therefore are not visible with an echo sounder in the so-called blind zone between the surface and $10 \mathrm{~m}$ depth (the transducer is fixed to the hull with a $5 \mathrm{~m}$ draft and $5 \mathrm{~m}$ to transmit pulse and transducer near field). Identification of species in the echo traces was conducted by fishing with a 76/70 pelagic trawl with a $20 \mathrm{~m}$ vertical opening and a $10 \mathrm{~mm}$ mesh cod end.

Acoustic data were collected along transects at a vessel speed of 9 knots with a calibrated OSSIAN 1500 split beam echo sounder. The frequency was $38 \mathrm{kHz}$, the beam angles were $8^{\circ} / 8^{\circ}$, and the pulse duration was $1 \mathrm{~ms}$. Using the first numerical interface INES-MOVIES (Weill et al. 1993), acoustic data were stored during the whole ERAG93 survey. For each ping, the sampling rate was $10 \mathrm{~cm}$ vertically. The ping rate varied according to bottom depth (e.g. at a vessel speed of 10 knots, a ping rate of $0.5 \mathrm{~s}$ provides samples of about $0.1 \mathrm{~m}$ in the vertical and $5 \mathrm{~m}$ in the horizontal along the sampled transect). Data were translated later in Hac standard format when available (ICES 2005). The objective was to isolate "acoustic objects" in order to characterize the spatial organization of fish. Each acoustic object consists of a set of samples forming a patch on the echogram. In this study, samples were considered acceptable if they had an amplitude $>-60 \mathrm{~dB}$ and showed contiguity from one ping to at least another one and between at least two samples within a single ping, without any gap between, vertically and horizontally.

To describe each definite acoustic object, 41 morphological, bathymetric, and energetic parameters were calculated. A meta-analysis on various pelagic stocks in Europe (CLUSTER EU project: Muiño et al. 2003), including the Bay of Biscay, has showed that these descriptors were repeatedly correlated in a similar way and three main leading factors were retained to be used as reliable descriptors: size, density and depth in the water column. In this study, only two were taken into account considered as sufficient to describe the aggregative pattern and vertical distribution in the water column of the present fish community: the density $\left(S_{v s}\right)$ and the vertical position $\left(A_{\min }\right)$. 
$\mathrm{S}_{\mathrm{vs}}(1)$ is the volume reverberation index of the school. Being the acoustic density inside a school, Svs is considered to be representative of the level of concentration of fish within a school, and so related to the level of organization of fish.

$$
\text { (1) } S_{v s}=10 \log \left[\frac{\sigma_{a g}}{A}\right]
$$

where $\sigma_{a g}$ is the aggregate backscattering cross-section in $\mathrm{m}^{2}$ and $A$ is the area of the school in $\mathrm{m}^{2}$. This value is calculated by analogy with the echo integration by depth layer as described by MacLennan et al (2002), but in their study A represents the vertical area of the shoal in $\mathrm{m}^{2}$ instead of the surface of the depth layer in squared nautical miles $\left(\mathrm{nm}^{2}\right)$.

$A_{\min }$ is the distance between the lower part of the object and the bottom, and is therefore an indicator of the vertical position of fish in the water column.

To be considered a fish school in this study, acoustic objects (Figure 2) had to conform to the thresholds described in Table 1. All schools were considered, even if they were too small to be corrected by the Diner method (Diner 2001), to be sure that even the small objects were not rejected. This could be the case of small clupeids such as sprat and anchovy, which are often gathered in several very small schools instead of big aggregations or layers. In the offshore area, schools that were close to the surface $\left(A_{\min }>100\right)$ and with a low reverberation index $\left(S_{v s}<-53 \mathrm{~dB}\right)$ were parts of thick layers of plankton at the surface and therefore were rejected because there were not considered as fish schools.

A total of 3,303 schools were characterised according to thse rules (Table 2) along surveyed transects between the coast and $50 \mathrm{~m}$ depth in the GIR area and between $100 \mathrm{~m}$ and $150 \mathrm{~m}$ depth in the FAC area before and after the wind stress (Figure 1).

\section{Anchovy sampling and sample processing}

Sampling of anchovies was conducted by picking up 10 individuals from each of the 14 trawl catches: Fish were taken at random and damaged individuals discarded. This occurred more frequently when large quantities of horse mackerel were also caught. A small sample of the white trunk muscle was excised from the dorsal part of the body between the midpoint of the back head-front and the back dorsal fin point. The size of the sample varied coarsely with the size of the individual (i.e. from 0.5 to $1.6 \mathrm{~g}$ fresh weight for individual lengths between 120 and $170 \mathrm{~mm}$ ). Each sample was placed into a cryovial, immediately frozen at $-40^{\circ} \mathrm{C}$, and kept at this temperature until analysis in the laboratory few weeks after the end of the cruise. Nucleic acids are rather tough molecules (Ferguson and Drahushchak 1989) and it has been verified that such preservation conditions gave totally satisfactory results.

\section{Biochemical analyses}

Nucleic acid quantities in fish tissues have been measured for many years in our laboratory. Because early works in this field were devoted to fish larvae (Bergeron et al. 1991; Bergeron and Boulhic 1994; Bergeron 2000), the search for the highest sensitivity led us to consider fluorimetric methods, which gave satisfactory results in the case of very small quantities (i.e. the individual larval fish level). For samples of adult white muscle, there was no need for this level of sensitivity. Nevertheless, the routine use of the fluorimetric method practised for many years in rigorously standardised conditions in our laboratory tempted us to use the same technique for larger samples. Therefore, the most delicate step preceding the analysis itself was the dilution technique used to obtain a nucleic acid quantity within the proper range 
for an accurate measurement. Any possible small error would be reduced by the fact that the result consists of the ratio of two quantities measured in a single sample.

After thawing in the laboratory, the small pieces of white trunk muscle were ground with a Polytron in varying volumes $(\mathrm{V}$ in $\mathrm{ml})$ of ice-cold distilled water $\left(4^{\circ} \mathrm{C}\right)$. The volume of each sample was adjusted according to a relation with its fresh weight ( $F W$ in $g$ ) (i.e. $V=50^{*} \mathrm{FW}$ ) to optimise the range of nucleic acid values and thereby increase the accuracy of the measurements. A sub-sample of this homogenate was taken and subjected to a second homogenisation $\left(4^{\circ} \mathrm{C}\right)$ using a Potter-Elvehjem, which eliminated the smallest particles that can prevent stable fluorescence measurements. This sample was immediately processed, in triplicate, for nucleic acid determination by the fluorimetric method based on the use of ethidium bromide, initially described by Le Pecq and Paoletti (1966) and modified by Karsten and Wollenberger $(1972,1977)$. We used the conditions tested and defined by Bergeron and Boulhic (1994), with type I DNA (Sigma ${ }^{\circledR}$, St. Louis, MO, USA) from calf thymus as the standard. The analytical conditions were quite close to those more recently recommended for nucleic acid determination in fish larvae (ICES 2004), small differences being tied to working on white muscle of fish, i.e. on more homogeneous tissue than a whole body of larval fish. It must be specified that possible influences of factors such as sex, size or age (and even sampling time within 24 hours periods) on the determination of the RNA/DNA ratio had been previously tested (Bergeron, unpublished data) and none of these factors proved to have any significant effect.

The results of the RNA/DNA ratio estimates were subjected to an analysis of variance (ANOVA) to characterize the differences between all individuals caught in each of the two sampled areas before and after the strong wind event, thus the whole data set included four groups of variables.

\section{Results}

During the second leg of the ERAG 93 cruise, two days were devoted to acoustic prospection. Two sampling trawls in both the GIR and FAC areas were conducted (Figure 3). Afterwards, an unusual strong wind event occurred, with speeds of 20-30 knots continuously blowing for three days (Figure 3). This event affected the vertical structure of the water column (illustrative figures are given in Bergeron 2000). During the six days following the wind event, acoustic prospection and fish samplings (four trawling operations in GIR, six in FAC) were conducted in the study areas.

The characteristics of the fish schools, number of objects, altitude (height above the bottom in the water column), density averages and respective standard deviations (Table 2) show that regardless of the number of nautical miles surveyed, the presence of schools and their densities were quite similar in each area before and after the wind event. In both areas, anchovies were present both before and after the event. Species compositions provided by pelagic trawl hauls showed that the assemblage of species did not change in the GIR area but did change in the FAC area. Anchovy was the dominant species (95\%) in the FAC area before the wind event, but it represented only $10 \%$ of the assemblage after the event due to an increment in the abundance of horse mackerel. In addition, densities of fish schools were lower offshore than inshore, but this difference can be explained mainly by technological factors. The beam width is greater close to $100 \mathrm{~m}$ depth compared to $<50 \mathrm{~m}$, which artificially increases the size of the schools and their densities (Diner 2001). However, altitudes of schools seemed to vary more offshore than inshore.

In our analyses, we considered the position of the shoals in the water column in relation to the bottom, separately for each area before and after the wind event (Figure 4). In the GIR area, schools were always detached from the bottom, and $50 \%$ of them gathered at $5-7 \mathrm{~m}$ over the bottom. This group of schools was slightly more removed from the bottom after the wind event than before it, but they still occupied the same water column depth (i.e. between the bottom and $15 \mathrm{~m}$ above it). In the FAC area (Figure 4), the schools also were detached 
from the bottom at a height of $45 \mathrm{~m}$ in the water column before the wind stress $(50 \%$ were found at a height $>30 \mathrm{~m}$ in the water column). However, they were found near the bottom and strongly concentrated in a layer $<10 \mathrm{~m}(50 \%$ of them) after the wind event, but some outliers ( $<10 \%$ of the values) are responsible of biasing the mean position towards the surface layer (Figure 4). Thus, the fish in the inshore area did not change their distribution or were able to recover their previous vertical distribution after the wind event, whereas the fish in the offshore area were compressed very close to the bottom after the wind event (Figure 4).

The nutritional condition of anchovies was estimated using their RNA/DNA ratios (Figure 3). The ratios were clearly beyond the threshold of 2 and thus the nutritional condition was maintained at a suitable value. Moreover, the ratio did not differ statistically between the GIR and FAC areas before the wind event (Table 3). After the wind event, the mean RNA/DNA value decreased sharply and significantly in the FAC area, whereas it remained the same as that before the event in the GIR area $\left(F_{(3,136)}=21.699, p<0.001\right.$, Table 3).

\section{Discussion}

Wind conditions are abundantly mentioned in the literature for their effects in fisheries ecology at multiple time and space scales (e.g. Peterman and Bradford 1987; Dickson et al. 1988; Lloret et al; 2004), many studies have shown how these effects are transmitted through the nano-microplankton community (Nielsen and Kiørbe 1991; Wetz and Paerl 2008) and through their impact on mesozooplankton metabolism (Mayzaud et al. 1994). The strong wind event that occurred in the southern Bay of Biscay in 1993 and its effects on the larval anchovy population has been described previously. Bergeron (2000) reported that the wind stress had a detrimental effect on the larvae, but also that the larval population was only partly affected. In the present study, we found a similar effect on adult spawners: The whole adult population was not equally affected by the wind event; rather, we found spatial specificities. The behaviour patterns of fishes tend to change when the surface becomes rougher in response to strong winds (Ehrich and Stransky 1999). About small pelagic fishes, fishermen describe this phenomenon by saying the "fish is diving" (Gerlotto et al. 1997) or dispersing. This assertion appeared to be true in the ocean-like FAC area but not in the coastal area under the influence of the Gironde river plume. Moreover, the wind event seems to have affected not only the behaviour of small pelagic fish shoals but also the nutritional condition of fishes (at least anchovies) in the offshore area. These changes occurred only at the FAC area in ocean-like conditions, while fishes living in shallower water near the Gironde plume did not show any comparable change. This difference might be related to differences in the stability of the water column in the two areas. As mentioned by Mann and Lazier (1991), addition of fresh water to salt water causes early stratification and great resistance to breakdown of thermal stratification by tidal or wind-induced mixing. In contrast, the thermocline that forms in the open sea is much less robust, thus the associated primary producers and the whole community of planktonic organisms are likely to be scattered under turbulent environmental conditions, promoting a disruption of the hydrobiological structure of the water column (e.g. Nogueira et al. 2000), which in turn can have disastrous consequences for consumers such as copepods and fish larvae. The well-balanced trophic relationships between small-sized organisms at the base of the pelagic food web are disrupted, which has been described either in open sea (e.g. Andersen et al. 2001) or in coastal waters (e.g. Lagadeuc et al. 1997). In our present study, the coastal area is protected from such a disruption by the continuous freshwater running off from the Gironde estuary, according to the notion presented by Mann and Lazier (ibid.). This scenario occurred in the FAC region during the 1993 wind event, and Bergeron (2000) described the effects on anchovy larvae. He also provided a good field illustration of the famous "stable ocean" concept advanced by Lasker (1975). The novelty of our present data set is that we show an 
analogous dramatic effect at a higher trophic level: adult anchovies that are essentially consumers of copepods (Plounevez and Champalbert 1999). To our knowledge it is the first report of such an event fortuitously encountered in the field, i.e. the simultaneous effect of a strong wind on the shoaling behaviour and the nutritional condition of a small pelagic species in a thermo-stratified open-sea area. It appears to be unquestionable that the stability of the water column plays a fundamental role on the hydrobiological environment of fishes (Lasker 1975; Coyle et al. 2008). In the present case, without being able to advance any coherent and well-supported, unquestionably founded explanation on relationships between physical driving forces originating instability of the water column and its diverse inhabitants, from bacteria to zooplankton, it is widely admitted that turbulent phenomena have an effect on biological processes (Mann and Lazier 1991): this effect can be either positive or negative depending on the strength of the physical forcing and the biological process considered, it is often defined between both extreme limits an "optimal window" (Cury and Roy 1989; Gargett 1997). Anyway, the research team on board RV Thalassa had not sufficient means for investigating further the biological consequences of the fortuitous event encountered during the ERAG 93 cruise, which could only be analysed after the end of the cruise. Strictly mechanistic explanations of the observed phenomenon remain unclear, these have got most probably something to do with disruptions of micro-aggregation patterns of smallest particles living in the sea (leading us to the innovative ways towards the new and vast research field opened in the early eighties by Tom Fenchel and his collaborators: Azam et al. 1983; Fenchel and Finlay 2003; Esteban et al. 2010) and undoubtedly with other gaps still existing in our knowledge of oceanography.

The proportion of horse mackerel increased after the wind event in both study areas (to a smaller extent in the GIR area than in FAC) and a sudden occurrence of a large biomass of this fish in the FAC area has most probably played a role in the observed downward displacement of the whole of schools to a layer very near the bottom. It is in accordance with the classical behaviour of horse mackerel, which is rather making up big schools or layers close to the bottom. Anchovy, when mixed with horse mackerel, is able to divide into another separate level and to remain above horse mackerel (Massé et al. 1996), i.e. to have its own behaviour allowing probably to draw better trophic benefits and also to avoid possible predation by the largest individuals of the horse mackerel population, as hypothesized by Massé et al. (1996). In the first four out of six trawl catches collected after the strong wind event, the horse mackerel biomass consisted mainly of large or average sized individuals; small strictly zooplanktophagous individuals (i.e. competitors of anchovies for feeding) appeared only in the two last catches. Therefore, it seems unlikely that competition for similar sized prey can explain the observed decrease in the nutritional condition of anchovies. After the wind event, anchovies constituted $10 \%$ of the species composition; these anchovies most likely were distributed slightly above the layer occupied by horse mackerel according to the pattern described by Massé (1996). The examination of the long data series acquired over the years permits us to state that the co-existence of horse mackerel with anchovy is a usual pattern in the Bay of Biscay, but we have not observed a coincidental detrimental effect on anchovy nutritional state (Bergeron and Massé, unpublished data). The data showed that the wind event reduced the nutritional condition of anchovies, but it is unlikely that the presence of horse mackerel was responsible.

Because of the essential role of nutrition in sustaining the gemetogenesis process in fishes, the phenomenon put forward in this study may have consequences on the overall fecundity of the anchovy population, although at regional scale. In a review of the biology of clupeoid fishes, Blaxter and Hunter (1982) indicated that a large majority of these small pelagic species reproduce using a multiple (serial or asynchronic) spawning strategy. Motos (1996) confirmed that the Bay of Biscay anchovy is a multiple spawner with asynchronous development of oocytes: de novo vitellogenesis is a continuous process during the reproductive season and all oocyte stages are present at the same time in the ovary. Motos (1996) estimated that during an annual spawning season, the Bay of Biscay anchovy could spawn about 19-20 times. This number is very close, if not quite the same (20), to that established by Hunter and Leong (1981) for the northern anchovy Engraulis mordax. These 
authors reported that because the caloric equivalent of only two spawnings exists in the ovary at one time, northern anchovies must use energy stored in other tissues and food intake to support reproduction. They also calculated that a daily ration of copepods equivalent to $4-5 \%$ of female wet weight per day is required to support the annual cost of growth and reproduction. It is quite possible that the European anchovy inhabiting the Bay of Biscay, given its highly dynamic growth and sexual maturation characteristics (Motos 1996), has larger metabolic requirements.

According to Blaxter and Hunter (1982), selection of specific spawning sites is related to good feeding conditions for adults. Such good conditions in the Bay of Biscay are driven by different physical processes that lead to local enrichments in basic nutrients (Koutsikopoulos and Le Cann 1996), and these are responsible for the relatively reproducible year-to-year spatial distribution patterns of spawning anchovies (Motos et al. 1996). However, strong annual quantitative differences may exist in processes occurring in these spawning sites (e.g., varying outflow rates of nutrient-rich freshwater from the Gironde Estuary). These variations have consequences on the food stock (essentially copepods, as shown by Plounevez and Champalbert 1999) in terms of biomass and dynamics of production. Special events such as strong wind events are likely to modify the functional characteristics of these spawning sites on different temporal and spatial scales and to some extent to restrict the metabolism of breeding anchovies. In the present case, it is unfortunate that the ERAG 93 cruise did not last longer so that we could estimate the duration of the lowered anchovy nutritional state in the FAC area.

\section{Acknowledgements}

We are greatly indebted to the whole team of colleagues who contributed to the execution of the ERAG 93 research cruise, in particular Patrick Grellier for his management of the sorting of trawled fishes and Nathalie Rétière for carrying out biochemical analyses. Thanks are due to officers and crew of the RV Thalassa. Recommendations from two anonymous reviewers permitted to substantially improve the presentation of this work, which is very much appreciated. This study was carried out within the framework of the "Programme National sur le Déterminisme du Recrutement" (PNDR), a French contribution to the GLOBEC (SPACC) International Program.

\section{References}

Albaina A, Irigoien X. 2004. Relationships between frontal structures and zooplankton communities along a cross-shelf transect in the Bay of Biscay (1995 to 2003). Mar Ecol Prog Ser. 284:65-75.

Andersen V, Gubanova A, Nival P, Ruellet T. 2001. Zooplankton community during the trasition from spring bloom to oligotrophy in the open NW Mediterranean and effects of wind events. 2. Vertical distributions and migrations. J Plankton Res. 23:243-261.

Azam F, Fenchel T, Field JG, Gray JS, Meyer-Reil LA, Thingstad F. 1983. The ecological role of water-column microbes in the sea. Mar Ecol Progr Ser. 10:257-263.

Bergeron J-P. 1997. Nucleic acids in ichthyoplankton ecology: a review, with emphasis on recent advances for new perspectives. J Fish Biol. 51(Supplement A):284-302.

Bergeron J-P. 2000. Effect of strong winds on the nutritional condition of anchovy (Engraulis encrasicolus L.) larvae in the Bay of Biscay, Northeast Atlantic, as inferred from an early field application of the DNA/C index. ICES J Mar Sci. 57:249-255.

Bergeron J-P, Boulhic M. 1994. Rapport ARN/ADN et évaluation de l'état nutritionnel et de la croissance des larves de poissons marins: un essai de mise au point expérimentale chez la sole (Solea solea L.). ICES J Mar Sci. 51:181-190. 
Bergeron J-P, Boulhic M, Galois R. 1991. Effet de la privation de nourriture sur la teneur en ADN de la larve de sole (Solea solea L.). ICES J Mar Sci. 48:127-134.

Bergeron J-P, Delmas D, Koueta N. 2009. Determining how the pelagic ecosystem over the continental shelf of the Bay of Biscay (NE Atlantic) functions: An approach using mesozooplankton enzyme activities as descriptors. Estuar Coast Shelf Sci. 82:254-264.

Blaxter JHS, Hunter JR. 1982. The biology of clupeoid fishes. Adv Mar Biol. 20:1-223.

Certain G, Bellier E, Planque B, Bretagnolle V. 2007. Characterising the temporal variability of the spatial distribution of animals: An application to seabirds at sea. Ecography 30:695708.

Certain G, Ridoux V, van Canneyt O, Bretagnolle V. 2008. Delphinid spatial distribution and abundance estimates over the shelf of the Bay of Biscay. ICES J Mar Sci. 65:656-666.

Chicharo MA, Chicharo L. 2008. RNA:DNA ratio and other nucleic acid derived indices in marine ecology. Int J Mol Sci. 9:1453-1471.

Coyle KO, Pinchuk Al, Eisner LB, Napp JM. 2008. Zooplankton species composition, abundance and biomass on the eastern Bering Sea shelf during summer: The potential role of water-column stability and nutrients in structuring the zooplankton community. Deep-Sea Res II 55:1775-1791.

Cury P, Roy C. 1989. Optimal environmental window and pelagic fish recruitment success in upwelling areas. Can J Fish Aquat Sci. 46:670-680.

Dickson RR, Kelly PM, Colebrook JM, Wooster WS, Cushing DH. 1988. North winds and production in the eastern North Atlantic. J Plankton Res. 10:151-169.

Diner N. 2001. Correction on school geometry and density: Approach based on acoustic image simulation. Aquat Living Resour. 14:211-222.

Ehrich S, Stransky C. 1999. Fishing effects in northeast Atlantic shelf seas: patterns in fishing effort, diversity and community structure. VI. Gale effects on vertical distribution and structure of a fish assemblage in the North Sea. Fish Res. 40:185-193.

Esteban GF, Fenchel T, Finlay BJ. 2010. Mixotrophy in ciliates. Protist. 161:621-641.

Fenchel T, Finlay BJ; 2003. Is microbial diversity fundamentally different from biodiversity of larger animals and plants? Europ J Protistol. 39:486-490.

Ferguson MM, Drahushchak LR. 1989. Effects of tissue collection and storage methods on nucleic acid determinations in white muscle of fishes. Trans Am Fish Soc 118:709-713.

Fulton TW. 1904. The rate of growth of fishes. Fisheries Board of Scotland, Annual Report 22:141-241.

Gargett AE. 1997. The optimal stability "window": a mechanism underlying decadal fluctuations in North Pacific salmon stocks? Fish Oceanogr. 6:109-117.

Gerlotto F, Petitgas P, Cussat-Legras A-S. 1997. Effect of meteorological events on the spatial distribution of schools and their typology: Impact on the validity of acoustic surveys. ICES CM 1997/Y 28.

Hunter JR, Leong R. 1981. The spawning energetics of female northern anchovy, Engraulis mordax. Fish Bull. 79:215-230.

ICES 2004. Recruitment studies: Manual on precision and accuracy of tools. By M Belchier, C Clemmesen, D Cortes, T Doan, A Folkvord, A Garcia, A Geffen, H Høie, A Johannessen, E Moksness, H de Pontual, T Ramirez, D Schnack, B Sveinsbo. ICES Techniques in Marine. Environmental Sciences No 33, 35pp.

ICES 2005. Description of the ICES HAC standard data exchange format, version 1.60. ICES Cooperative Research Report, No 278, 86pp.

Karsten U, Wollenberger A. 1972. Determination of DNA and RNA in homogenized cells and tissues by surface fluorometry. Anal Biochem. 46:135-148.

Karsten U, Wollenberger A. 1977. Improvements in the ethidium bromide method for direct fluorometric estimation of DNA and RNA in cell and tissue homogenates. Anal Biochem. 77:464-470.

Koutsikopoulos C, Le Cann B. 1996. Physical processes and hydrological structures related to the Bay of Biscay anchovy. Sci Mar. 60(Supplement 2):9-19.

Lagadeuc Y, Boulé M, Dodson JJ. 1997. Effect of vertical mixing on the vertical distribution of copepods in coastal waters. J Plankton Res. 19:1183-1204. 
Lampert L, Quéguiner B, Labasque, T, Pichon A, Lebreton N. 2002. Spatial variability of phytoplankton composition and biomass on the eastern continental shelf of the Bay of Biscay (north-east Atlantic Ocean). Evidence for a bloom of Emiliania huxleyi (Prymnesiophyceae) in spring 1998. Cont Shelf Res. 22:1225-1247.

Lasker, R., 1975. Field criteria for survival of anchovy larvae: the relation between inshore chlorophyll maximum layers and successful first feeding. Fish. Bull. 73, 453-462.

Le Pecq JB, Paoletti C. 1966. A new fluorometric method for RNA and DNA determination. Anal Biochem. 17:100-107.

Lloret J, Palomera I, Salat J, Sole I. 2004. Impact of freshwater input and wind on landings of anchovy (Engraulis encrasicolus) and sardine (Sardina pilchardus) in shelf waters surrounding the Ebre (Ebro) River delta (north-western Mediterranean). Fish Oceanogr. 13:102-110.

Mann KH, Lazier JRN. 1991. Dynamics of marine ecosystems. Biological-physical interactions in the oceans. Blackwell Scientific Publications, Boston.

MacLennan DN, Fernandes PG, Dalen J. 2002. A consistent approach to definitions and symbols in fisheries acoustics. ICES J Mar Sci. 59:365-369.

Massé J. 1996. Acoustics observation in the Bay of Biscay: schooling, vertical distribution, species assemblages and behaviour. Sci Mar. 60(Supplement 2):227-234.

Massé J, Koutsikopoulos C, Patty W. 1996. The structure and spatial distribution of pelagic fish schools in multi-species clusters: an acoustic study. ICES J Mar Sci. 53:155-160.

Mayzaud P, Biggs DC, Roche-Mayzaud O. 1994. Short-term variability of metabolic and digestive enzyme activity on naturally occurring populations of adult copepod Acartia clausi. Ecoscience 1:195-207.

Motos L. 1996. Reproduction biology and fecundity of the Bay of Biscay anchovy population (Engraulis encrasicolus L.). Sci Mar. 60(Supplement 2):195-207.

Motos L, Uriarte A, Valencia V. 1996. The spawning environment of the Bay of Biscay anchovy (Engraulis encrasicolus L.). Sci Mar. 60(Supplement 2):117-140.

Muiño R, Carrera P, Petitgas P, Beare DJ, Georgakarakos S, Haralambous J, Iglesias M, Liorzou B, Massé J, Reid D. 2003. Consistency in the correlation of school parameters across years and stocks. ICES J Mar Sci. 60:164-175.

Nash RDM, Valencia AH, Geffen AJ. 2006. The origin of Fulton's condition factor- Setting the record straight. Fisheries 31:236-238.

Nielsen TG, Kiørbe T. Effect of a storm event on the structure of the pelagic food web with special emphasis on planktonic ciliates. J Plankton Res. 13:35-51.

Nogueira E, Ibanez F, Figueiras FG. 2000. Effect of meteorological and hydrographic disturbances on the microplankton community structure in the Ria de Vigo (NW Spain). Mar Ecol Prog Ser. 203:23-45

Peterman RM, Bradford MJ. 1987. Wind speed and mortality rate of a marine fish, the northern anchovy (Engraulis mordax). Science 235:354-356.

Plounevez S, Champalbert G. 1999. Feeding behaviour and trophic environment of Engraulis encrasicolus (L.) in the Bay of Biscay. Estuar Coast Shelf Sci. 49:177-191.

Ribeiro R, Reis J, Santos C, Gonçalves F, Soares AMVM. 1996. Spawning of anchovy Engraulis endrasicolus in the Mondego Estuary, Portugal. Estuar Coast Shelf Sci. 42:467482.

Weill A, Scalabrin C, Diner N. 1993. MOVIES B: An acoustic detection description software. Application to shoal species classification. Aquat Living Resour. 6:255-267.

Wetz MS, Paerl HW. 2008. Impact of large storm events with different meteorological characteritics on estuarine ciliate biomass. J Plankton Res. 30:551-557.

Zarauz L, Irigoien X, Urtizberea A, Gonzalez M. 2007. Mapping plankton distribution in the Bay of Biscay during three consecutive spring surveys. Mar Ecol Prog Ser. 345:27-39. 


\section{Figures}

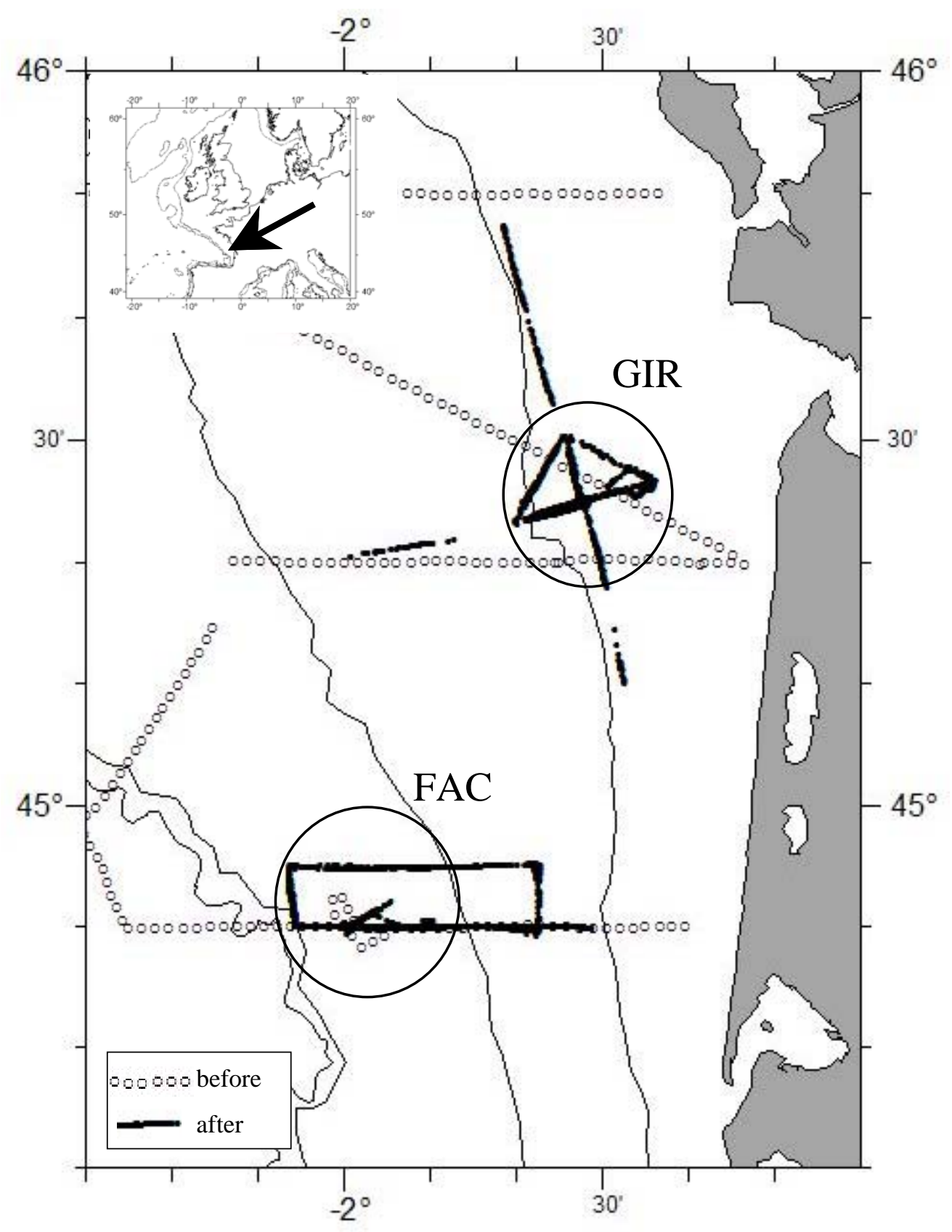

Figure 1. Chart of the sampling area. Two circles delineate the area influenced by the Gironde estuarine plume (GIR) and the area located in the continental shelf-break (FAC) where fine-scale sampling was carried out. 


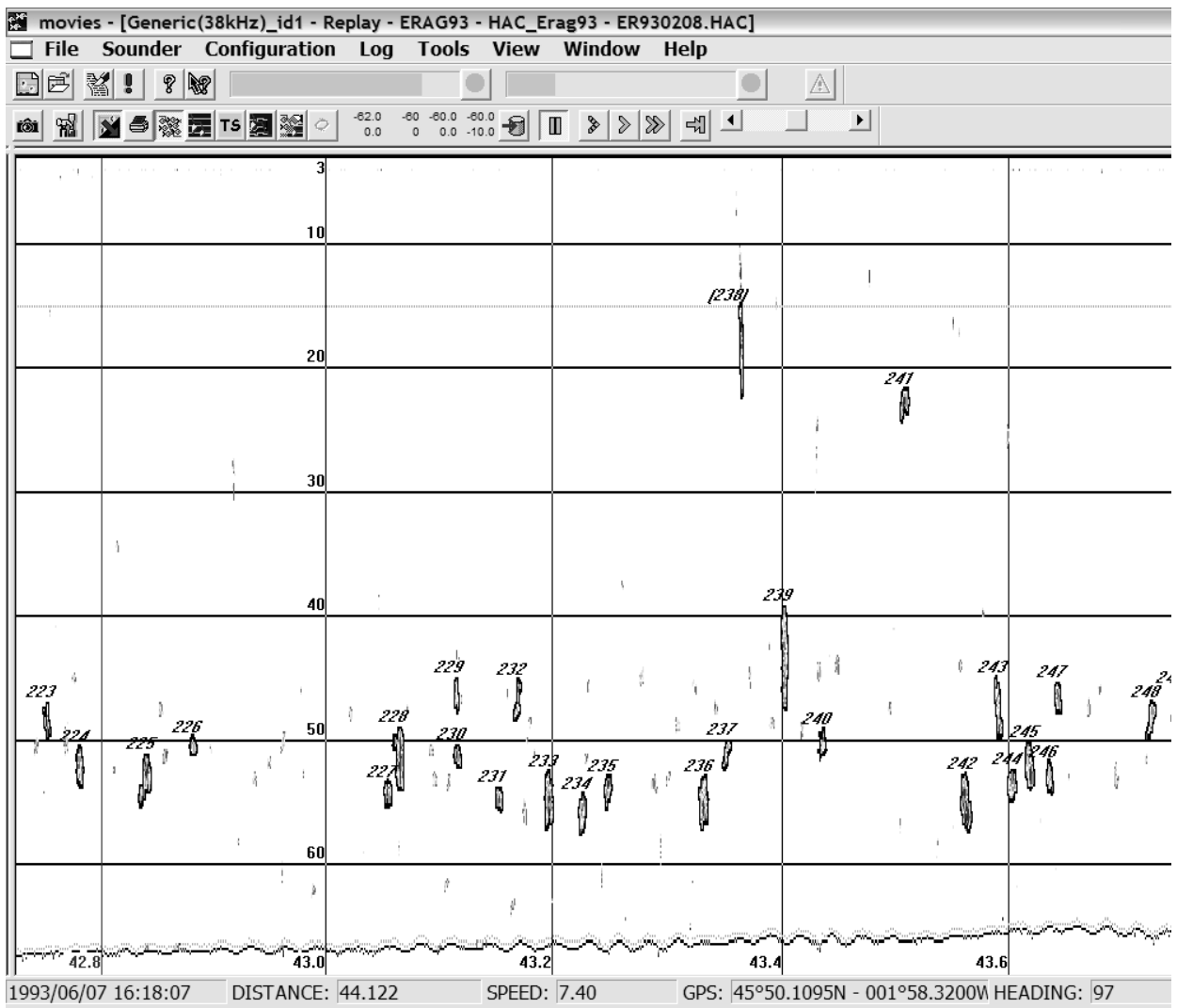

Figure 2. Example of an echogram depicted by means of the MOVIES software, showing some "acoustic objects" recorded by the echo sounder.

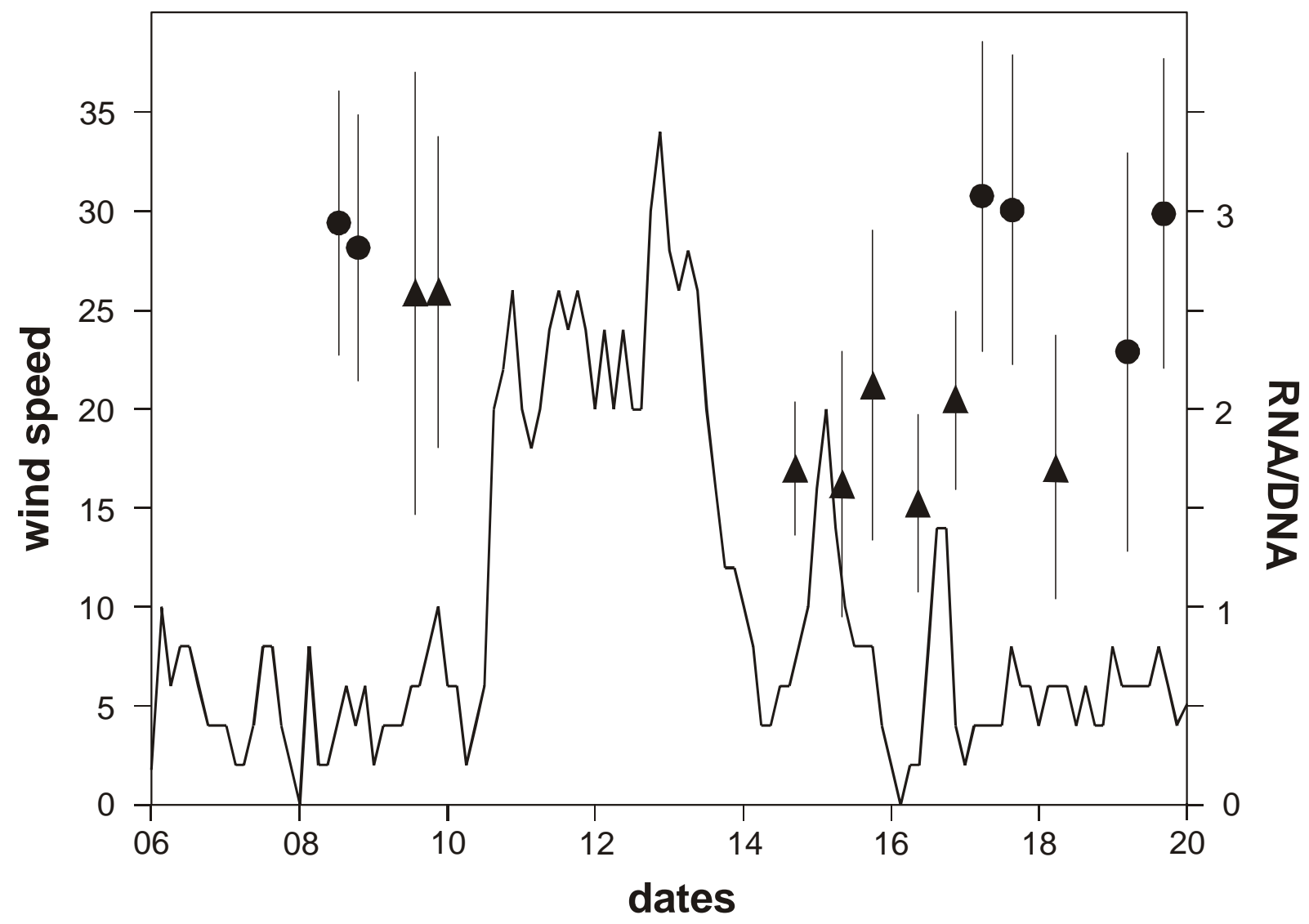


Figure 3. Time series of wind speed (in knots) and mean RNA/DNA ratio determined in samples of anchovies from GIR (circles) and FAC (triangles).

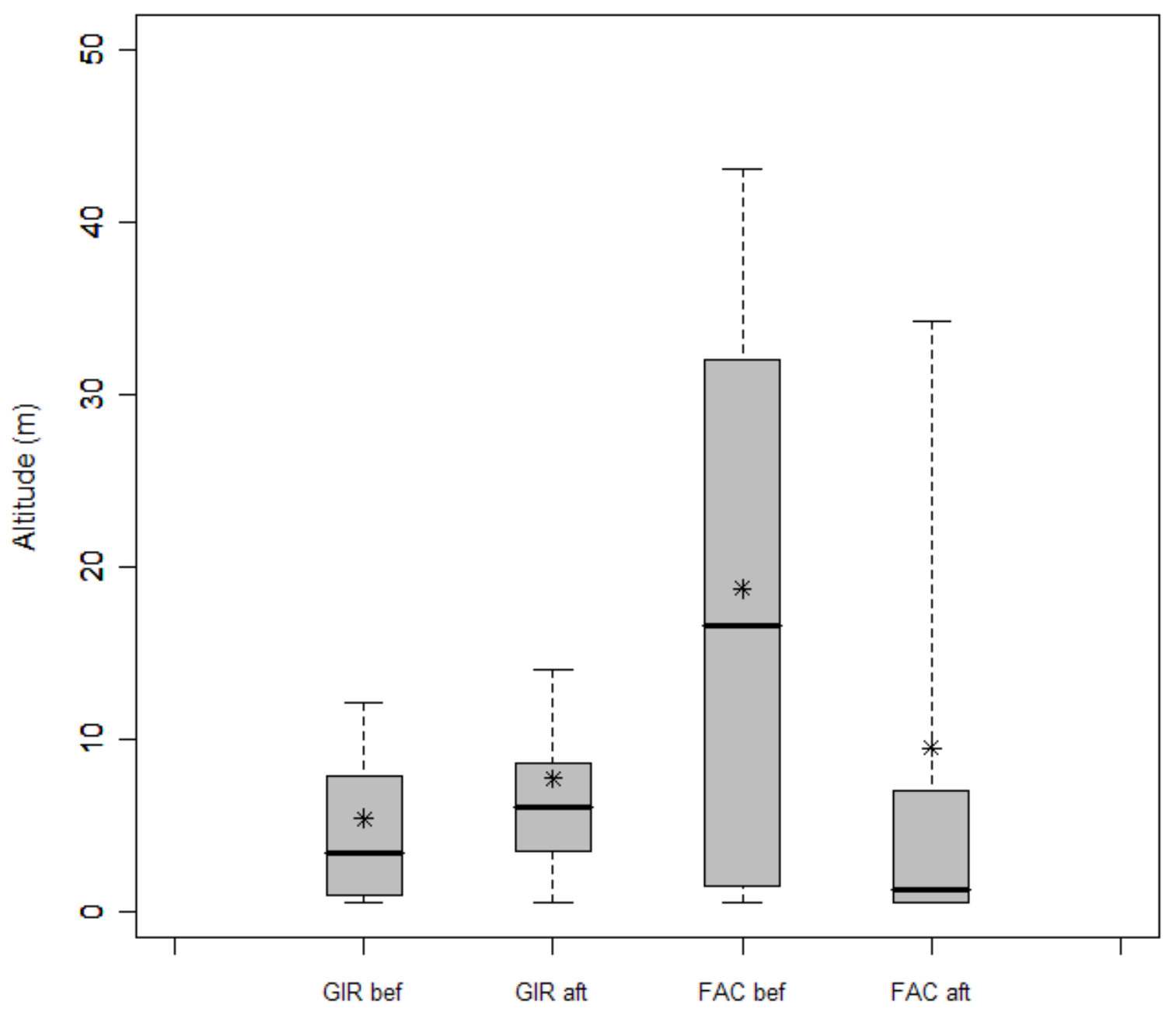

Figure 4. Vertical distribution of fish before and after the occurrence of the strong wind event in both sampling areas. Box plots represent $50 \%$ of the values within the grey boxes, $90 \%$ are gathered between whiskers, the thick horizontal line represents the median value and the asterisk indicates the average value. 
Table 1.

Main criteria retained for the definition of the "acoustic objects".

\begin{tabular}{cccccc}
\hline & $\begin{array}{c}\text { sample energy } \\
\text { threshold }(\mathrm{dB})\end{array}$ & $\begin{array}{c}\text { school length } \\
(\mathrm{m})\end{array}$ & $\begin{array}{c}\text { school height } \\
(\mathrm{m})\end{array}$ & $\begin{array}{c}\text { school area } \\
\left(\mathrm{m}^{2}\right)\end{array}$ & $\mathrm{S}_{\mathrm{vs}}(\mathrm{dB})$ \\
\hline Min & -60 & 5 & 1 & 10 & -53 \\
Max & 0 & 1000 & 100 & $10^{5}$ & 0 \\
\hline
\end{tabular}

Table 2.

Summary of the "acoustic objects" (schools) characterizing the fish presence and anchovy (An) and horse mackerel (HM) percentages (in weight) present in the catches*, before (bef) and after (aft) the strong wind event.

\begin{tabular}{|c|c|c|c|c|c|c|c|}
\hline & $\begin{array}{l}\text { no. of } \\
\text { schools }\end{array}$ & $\begin{array}{l}\text { no. nm } \\
\text { surveyed }\end{array}$ & $\begin{array}{l}\text { schools } \\
\text { no. / nm }\end{array}$ & $\begin{array}{l}\text { schools } \\
\text { mean } \\
\text { Svs (dB) }\end{array}$ & $S D$ & $\% A n$ & $\% \mathrm{HM}$ \\
\hline GIR bef* & 224 & 23 & 9.7 & -43.41 & 4.90 & 45 & 2 \\
\hline GIR aft & 740 & 78 & 9.5 & -43.92 & 4.74 & 57 & 34 \\
\hline FAC bef & 495 & 23 & 21.5 & -49.92 & 2.14 & 95 & 4 \\
\hline FAC aft & 1844 & 118 & 15.6 & -49.39 & 3.01 & 10 & 78 \\
\hline total & 3303 & 242 & & & & & \\
\hline \multicolumn{8}{|c|}{ *except sprat (42 \%) in GIR bef. } \\
\hline
\end{tabular}


Table 3.

Mean values and standard deviations of the RNA/DNA ratios

\begin{tabular}{lllll}
\hline & \multicolumn{2}{l}{ before wind stress } & \multicolumn{2}{c}{ after wind stress } \\
& mean & SD & mean & SD \\
& & & & \\
\hline GIR & 2.8 & 0.64 & 2.8 & 0.82 \\
FAC & 2.6 & 0.85 & $1.8^{*}$ & 0.57 \\
\hline
\end{tabular}

* highly significant difference $(p<0.001)$ with the three other means. 